\title{
Article \\ Crop Cycle and Tillage Role in the Outbreak of Late Wilt Disease of Maize Caused by Magnaporthiopsis maydis
}

\author{
Ofir Degani 1,2,*(D), Asaf Gordani ${ }^{1,2}$, Paz Becher ${ }^{1,2}$ and Shlomit Dor 1,2 \\ 1 Plant Sciences Department, Migal Galilee Research Institute, Kiryat Shmona 11016, Israel; \\ asigordani1@gmail.com (A.G.); pazbec@gmail.com (P.B.); dorshlomit@gmail.com (S.D.) \\ 2 Faculty of Sciences, Tel-Hai College, Tel-Hai 12210, Israel \\ * Correspondence: d-ofir@bezeqint.net or ofird@telhai.ac.il; Tel.: +972-54-678-0114
}

Citation: Degani, O.; Gordani, A.; Becher, P.; Dor, S. Crop Cycle and Tillage Role in the Outbreak of Late Wilt Disease of Maize Caused by Magnaporthiopsis maydis. J. Fungi 2021, 7,706. https://doi.org/10.3390/ jof7090706

Academic Editor: Laurent Dufossé

Received: 20 July 2021

Accepted: 27 August 2021

Published: 28 August 2021

Publisher's Note: MDPI stays neutral with regard to jurisdictional claims in published maps and institutional affiliations.

Copyright: (c) 2021 by the authors Licensee MDPI, Basel, Switzerland. This article is an open access article distributed under the terms and conditions of the Creative Commons Attribution (CC BY) license (https:// creativecommons.org/licenses/by/ $4.0 /$ )
Abstract: The destructive maize late wilt disease (LWD) has heavy economic implications in highly infected areas such as Israel, Egypt, and Spain. The disease outbreaks occur near the harvest, leading to total yield loss in severe cases. Crop rotation has long been known as an effective means to reduce plant diseases. Indeed, agricultural soil conservation practices that can promote beneficial soil and root fungi have become increasingly important. Such methods may have a bioprotective effect against Magnaporthiopsis maydis, the LWD causal agent. In this two-year study, we tested the role of crop rotation of maize with either wheat or clover and the influence of minimum tillage in restricting LWD. In the first experiment, wheat and clover were grown in pots with LWD infected soil in a greenhouse over a full winter growth period. These cultivations were harvested in the spring, and each pot's group was split into two subgroups that underwent different land processing practices. The pots were sown with LWD-sensitive maize cultivar and tested over a whole growth period against control soils without crop rotation or soil with commercial mycorrhizal preparation. The maize crop rotation with wheat without tillage achieved prominent higher growth indices than the control and the clover crop cycle. Statistically significant improvement was measured in the non-tillage wheat soil pots in sprout height 22 days after sowing, in the healthy plants at the season's end (day 77), and in shoot and cob wet weight (compared to the control). This growth promotion was accompanied by a 5.8-fold decrease in pathogen DNA in the plant stems. The tillage in the wheat-maize growth sequence resulted in similar results with improved shoot wet-weight throughout the season. In contrast, when maize was grown after clover, the tillage reduced this parameter. The addition of commercial mycorrhizal preparation to the soil resulted in higher growth measures than the control but was less efficient than the wheat crop cycle. These results were supported by a subsequent similar experiment that relied on soil taken from commercial wheat or clover fields. Here too, the wheat-maize growth cycle (without permanent effect for the tillage) achieved the best results and improved the plants' growth parameters and immunity against LWD and lowered pathogen levels. In conclusion, the results of this study suggest that wheat and perhaps other crops yet to be inspected, together with the adjusted tillage system, may provide plants with better defense against the LWD pathogen.

Keywords: Cephalosporium maydis; crop rotation; crop protection; disease management; fungus; Harpophora maydis; late wilt; maize; real-time PCR; rhizosphere

\section{Introduction}

The importance of maize (Zea mays L., corn) cannot be over-emphasized, especially in developing countries [1]. Maize is produced annually more than any other grain, reflecting its importance globally [2]. Late wilt, a disease severely affecting maize fields throughout Israel [3], is characterized by rather rapid dehydration of the plants near maturity. It is considered the most harmful disease in commercial maize fields in Israel [4] and Egypt [5] and poses a significant threat in India [6,7], Spain, and Portugal [8]. The disease is gradually 
continuing to spread and is currently reported in at least eight countries. The causal agent is the fungus Magnaporthiopsis maydis [9], recognized by two additional synonyms, Cephalosporium maydis [10] and Harpophora maydis [11,12].

The pathogen can survive in the soil for long periods. When a susceptible host plant is seeded, the fungi can penetrate the plants' roots, causing root necrosis and affecting sprout development $[13,14]$. First aboveground symptoms usually appear later in the season as plants begin to flower and are enhanced under drought conditions [15,16]. When the growth session advances, $M$. maydis spreads upwards inside the plants' vascular system, disrupts the water supply and leads to dehydration [17]. In heavily infested fields planted with sensitive maize hybrids, late wilt may cause $100 \%$ infection and total yield loss [18]. If ears are produced, the kernels that do form are poorly developed and are infested with the pathogen.

M. maydis can survive and spread through seeds [19], infested soil, crop residues [20], or secondary hosts such as lupine [21], cotton [22,23], watermelon, and Setaria viridis (green foxtail) [24]. Various LWD prevention methods have been examined over the years, and some gained positive results in reducing LWD in commercial fields. These include balanced soil fertility $[25,26]$, adjusted tillage system and cover crop [27], watering the field [28], biological approaches (will be discussed in detail below), soil solarization [29], allelochemical [13], and chemical options [4,30-33]. However, none of these methods is currently being used in Israel. Instead, worldwide LWD is controlled by more economically effective management by developing genetically resistant maize cultivars [5,6,34].

The National Maize Program in the Agricultural Research Center in Giza, Egypt, identified many sources of resistance; the release of resistant cultivars since 1980 has significantly reduced late wilt losses in Egypt [35]. A breeding program for resistant germ lines has been operational in Israel for about a decade (Israel Northern R\&D, Migal-Galilee Research Institute, Kiryat Shmona, Israel). However, the presence of highly aggressive isolates of $M$. maydis $[36,37]$ may threaten these resistant maize cultivars. In addition, the pathogen could spread in relatively resistant plants that showed no symptoms. Infected seeds, even those of non-symptomatic plants, can spread the disease [3,19].

In 2017-2018, the search for a chemical application to control LWD led to an economically feasible solution $[4,18,31]$ in Israel. The successful treatment protocol is based on changing the maize cultivation method, changing the traditional irrigation method used in most corn-growing areas in Israel, and the sophisticated integration of Azoxystrobin-based pesticide mixtures in a schedule adapted to key points in the development of the disease.

Still, it was shown earlier that the pathogen is present in the host tissues of successfully chemically treated plants [32]. This finding hints at the potential risk that the pathogen will develop immunity to Azoxystrobin, the most effective antifungal compound against the late wilt pathogen $[4,18]$. Unfortunately, the rapid development of resistance to this fungicide and the consequential control failure in many crops has become increasingly problematic [38].

The growing trend of reducing pesticide use [39] raises the need for alternative ways of coping with severe fungal diseases such as the late wilt of maize. Indeed, biological eco-friendly control methods to restrict $M$. maydis and other phytopathogens are at the forefront of the current scientific effort. Two environmentally friendly strategies to control late wilt are presently in this scientific focus.

First, the use of Trichoderma sp. and other protective microorganisms as a biocontrol agent has been demonstrated in the past in culture media, in greenhouse plants, and in the field with very promising potential (most recently [40,41]). Likewise, we previously conducted two years of research with new Trichoderma species: T. asperelloides (T.203); T. longibrachiatum (T.7407 from marine source [42]); and T. asperellum (P1), an endophyte isolated in our laboratory from corn seeds of a strain susceptible to LWD [43]. These isolates prevented the pathogen's growth in culture plates, significantly reduced its establishment and development in seedlings' corn plant tissues, and resulted in significant improvement in growth and crop indices under field conditions $[16,44]$. 
Second, maintaining soil mycorrhizal fungi between seasons has proven to be an essential factor towards the same goal (summarized by [40]). Results from other phytopathogens suggest that under no-till cropping, selected cover crops or crops in a rotation could help build mycorrhizal communities that function throughout a sequence of several main crops [45]. Aggressive tillage combined with long periods where the field is unprocessed results in the destruction of the integrity of mycorrhizal networks. Maintaining the continuity and integrity of mycorrhizal networks in the soil may allow the plant to enjoy higher resistance to soil diseases [46], including late wilt disease [27]. Indeed, Arbuscular mycorrhizal fungi (AMF) have a proven ability to improve plant resistance to biotic and abiotic stresses by activated the plant's local and systemic defense mechanisms [47].

So far, this approach of strengthening the soil microbiome was poorly tested against the late wilt pathogen, M. maydis. This knowledge gap is now encouraging the exploration of this method's potential as part of an integrated control program to restrain the late wilt agent, as we will detail below. In the current study, this method was studied thoroughly and evaluated over two years. In the first year, the effect of crop rotations of wheat/maize or clover/maize and a simulation of tillage regimes (no-tillage or conventional tillage) was inspected in pots where LWD-susceptible maize cultivar was grown in infected soil. These treatments were compared to infected no-tillage soil and infected no-tillage soil + commercial mycorrhizal preparation (Resid MG [48], BioBee, Sde Eliyahu, Israel). In the second year, the field's soils after commercial cultivation of wheat, clover, or soil without previous winter growth were used. These soils underwent two different tillage regimes before maize cultivation-no-tillage or conventional tillage. The effectiveness of these practices on $M$. maydis pathogenesis was studied by evaluating the growth parameters throughout the season, estimating the disease symptoms, measuring yield production, and monitoring the pathogen's DNA inside the host tissues using quantitative real-time (qPCR)-based approach.

\section{Materials and Methods}

\subsection{Fungal Species and Growth Conditions}

The M. maydis isolate Hm-2 (CBS 133165, CBS-KNAW Fungal Biodiversity Center, Utrecht, The Netherlands) was isolated from diseased maize plants collected from Sde Nehemia (Hula Valley, Upper Galilee, northern Israel) in 2001 and identified as previously described [3,49]. The fungus was grown on solid, rich potato dextrose agar (PDA) (Difco, Detroit, MI, USA) medium in the dark at $28 \pm 1{ }^{\circ} \mathrm{C}$ for $4-7$ days before being used.

\subsection{The Preparation of Infected Sterilized Wheat Grains}

Infected sterilized wheat grains were used to spread the fungus in the soil, as previously described [50]. Wheat grains were soaked overnight in tap water. The grains were then dried for about four hours in a fume hood on paper towels and autoclave sterilized for $30 \mathrm{~min}$ at a temperature of $120^{\circ} \mathrm{C}$. Disinfected plastic $0.5 \mathrm{~L}$ boxes were used to inoculate $100 \mathrm{~g}$ sterilized wheat grains with $10 \mathrm{M}$. maydis mycelial discs. Mycelia disks $(6 \mathrm{~mm}$ in diameter) were taken from the margins of a 4-6-day-old fungal colony grown as described in Section 2.1. The boxes were sealed with a lid (that was tightened to the box using Saran wrap), covered with aluminum foil (to guarantee dark conditions), and incubated at $28 \pm 1{ }^{\circ} \mathrm{C}$ in the dark for 10 days.

\subsection{The Plant Inoculation Methodology}

The plant inoculation technique and maize growth were similar to that of Degani et al., 2019 and $2020[18,22]$. The inoculum method was based on the use of soil from a field, having a long history of LWD infection (Amir, Mehogi-1 plot, coordinates: $33^{\circ} 09^{\prime} 59^{\prime \prime} \mathrm{N}$ $35^{\circ} 36^{\prime} 52^{\prime \prime}$ E) $[4,18]$ and a complementary inoculation with the Hm-2 isolate that was carried out in two steps. First, $40 \mathrm{~g}$ of sterilized infected wheat seeds were mixed with the top $20 \mathrm{~cm}$ of each pot's soil one week before seeding the winter crops (wheat and clover). The same procedure was done in the control pots as well. These seeds were prepared as described 
in Section 2.2. Second, with the maize plants' aboveground emergence (in the summer season, 8 days after sowing, DAS), two $M$. maydis colony agar disks (6-mm-diameter, see Section 2.1) were added to the upper parts of the roots ( $4 \mathrm{~cm}$ beneath the ground surface).

\subsection{Crop Rotation and Tillage Effect in Pots over a Full Growing Season-The 2019 Experiment}

This study examined the effect of crop alternation and tillage on M. maydis' ability to cause LWD over a whole growth period in pots in an open greenhouse. A binary rotation (with phased entry) of wheat-maize or clover-maize was examined during the fall and the winter of 2019 until the summer of 2020 at Tel-Hai College, Upper Galilee, Northern Israel. Instead of experimenting in the field, the use of pots with naturally infested soil aimed at enhancing the soil inocula and achieving high and equable infection as much as possible. The use of pots also ensures providing a better isolate of each treatment's influence and controlling the water regime. It should be emphasized that pathogenicity experiments cannot rely upon natural soil infection alone, resulting in highly variable data. Even in a heavily infested area, the spreading of the pathogen is nonuniform [18,51]. The pathogen is dispersed in small quantities in the soil, and the disease spread is not uniform in the field.

The environment data recorded during the growing season were nearly optimal for the winter crops, maize growth season, and LWD burst, as we will specify below. Sixty $10 \mathrm{~L}$ pots were filled with local naturally infested peat soil as described above (Section 2.3). The soil was mixed with Perlite No. 4 (for the ground aeration) at a ratio of 2:1. The pots were placed on a metal table made of mesh to prevent the passage of roots to the ground. Each treatment included 10 independent replications (pots) and had two controls and four treatments (Figure 1):

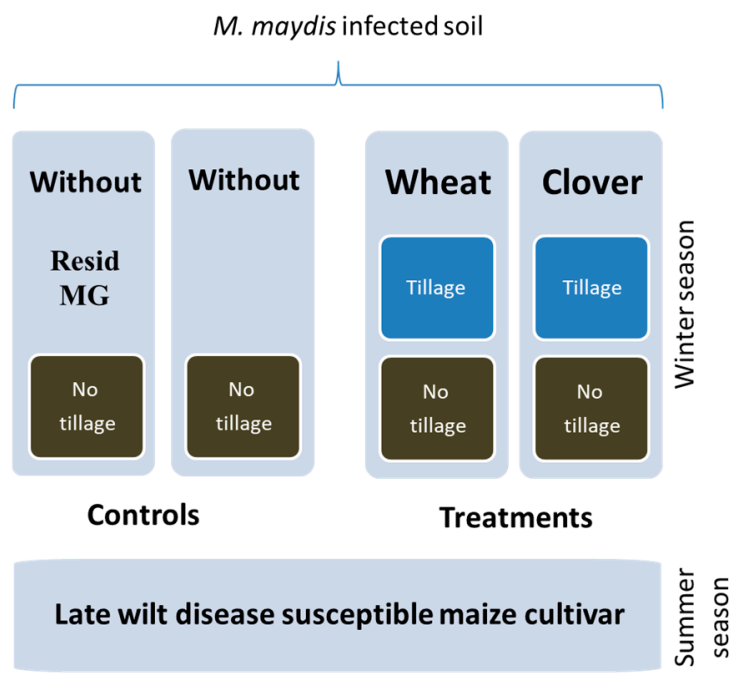

Figure 1. The 2019 experiment program. The experiment was conducted in pots in an open greenhouse over an entire growing season (winter season followed by spring-summer season). The late wilt susceptible maize genotype Prelude cv. was grown on M. maydis-infected soil in which wheat or clover had been grown as a crop prior to maize in this dual cultivation. The controls included the same prior crop soil but with tillage or soil that had not been cropped before the maize growth (control). Additionally, for comparison, the commercial Resid MG product of Arbuscular mycorrhizal, Glomus iranicum var. tenuihypharum (Symborg S.L., Murcia, Spain, supplied by BioBee Biological Systems, Sde Eliyahu, Israel) was tested as an addition to the soil that had not been cropped before growth.

(1) Infected control - naturally infested soil with the addition of complementary $M$. maydis infection (as described above). The pots with soil were kept all winter without a crop, and no-tillage was applied before the maize seeding in the spring.

(2) Commercial control-similar infected soil (without winter cropping or tillage) with the addition of commercial Resid MG [48] (or Bio-Up) product (Symborg S.L., Murcia, 
Spain, supplied by BioBee Biological Systems, Sde Eliyahu, Israel). This product contains $1.6 \times 10^{4}$ spores $/ \mathrm{kg}$ of the Arbuscular mycorrhizal, Glomus iranicum var. tenuihypharum, on clay particles. The preparation was added according to the manufacturer's instructions: $5 \mathrm{~g}$ of the product powder was added to the sowing pothole before sowing the corn.

$(3,4)$ Wheat-maize crop rotation-similar infected soil after the wheat growth season without tillage or with a simulation of conventional tillage. The last treatment was conducted using vigorous mixing and disintegration of the soil by pickaxe.

$(5,6)$ Clover-maize crop rotation-similar infected soil after the clove growth season with or without tillage.

\subsubsection{Winter Season}

The wheat cultivar Zahir was selected as a winter crop for this study. This hybrid is common in commercial fields in Israel due to its being suited for semi-desert conditions and rich in crops even under conditions of low rainfall. The clover cultivar was Tabor, an annual, single-harvest cultivar that is very popular among growers in Israel since it is suitable for most soils. Both wheat and clover cultivars were supplied by Hazera Seeds Ltd., Berurim MP Shikmim, Israel. The winter crops were seeded on December 11, 2018, and the aboveground parts were harvested (with minimum intervention in the soil integrity) on 29 April 2019, 139 DAS. The clover pots were treated after harvest with Carfentazone ethyl (kill broadleaf plants with no effect on Poaceae, Or, Tapazol Chemical Works Ltd., Beit Shemesh, Israel). The meteorological data recorded during the winter growing season were: temperature $12.9 \pm 5.1{ }^{\circ} \mathrm{C}$, humidity $78.6 \pm 20.7 \%$, radiation $147.5 \mathrm{~W} / \mathrm{m}^{2}$, precipitation $1566 \mathrm{~mm}$, and evaporation $424.0 \mathrm{~mm}$ (data-average \pm standard deviation according to the Israel Northern Research and Development meteorological station data, Hava-1). The irrigation commenced eight days later, five days before the beginning of the maize season.

\subsubsection{Summer Season}

On 12 May 2019, 13 days after the harvest of the winter crops, each of the pots was sown with five seeds of the maize Prelude cv. (a sweet variety, produced by SRS-Snowy River Seeds Australia, marketed by “Green 2000," Israel). This strain had been tested in the past and was shown to be highly susceptible to LWD [18,50]. Seeds were pre-treated with thiram, captan, carboxin, and metalaxyl-M (manufactured by Rogers/Syngenta Seeds, Boise, ID, USA, supplied by CTS, Tel Aviv, Israel), a standard general pesticide treatment. The seeds were tested for vitality before sowing and were buried in the ground at a depth of $4 \mathrm{~cm}$. The pots were marked and randomly scattered. The maize plants were harvested on 28 July 2019, 77 DAS. The meteorological data recorded during the growing season were nearly optimal for the LWD burst: temperature $26.8 \pm 6.2{ }^{\circ} \mathrm{C}$, humidity $55.3 \pm 12.6 \%$, radiation $359.7 \mathrm{~W} / \mathrm{m}^{2}$, precipitation $0.5 \mathrm{~mm}$, and evaporation $658.4 \mathrm{~mm}$ (data-average \pm standard deviation according to the Israel Northern Research and Development meteorological station data, Hava-1). Since it did not rain during the corn growing season, watering was carried out from seeding using 2 L per day per pot. Fertilizers and insecticide treatments were applied according to the Israel Ministry of Agriculture Consultation Service (SAHAM) growth protocol.

After eight days, the germination percentages were calculated. At 22 DAS, the sprouts were thinned to one plant per pot, and the thinned plants were used to evaluate the plants growth indices. On the female flowering day (56 DAS), the phenological stage and height of the plants were assessed. At the experiment's end (77 DAS), the plants' health status, height, fresh roots and shoot weight, and yield (total cob weight) of the treatments were measured. Wilt assessment was based on four categories related to the whole plant: healthy (1), minor symptoms (2), dehydrated (3), and dead (4). In addition, samples from the first internode of the plant stems were taken for DNA purification and qPCR. 


\subsection{Evaluation of Commercial Field Soil after Wheat or Clover Growth-The 2020 Experiment}

The 2020 experiment was conducted according to the same experimental design as in the 2019 experiment throughout a full growing season. This includes the same wheat, clover, and maize cultivars and the same soil inoculation protocol. The 2020 trial included four treatments and two controls and was performed in 10-12 repetitions-a total of 113 pots. It was conducted in a closed greenhouse on an experimental farm (R\&D North Israel, Kiryat Shemona, Israel) located in the Upper Galilee, Hula Valley, northern Israel. Commercial field soil after the winter growing season of clover and wheat, and soil after the winter without early growing (the last crop grown was watermelon in the last summer season) were taken from the fields of Moshav Moledet (Gilboa Regional Council, Lower Galilee, Israel). The soils were divided, and simulation of conventional tillage or no-tillage was applied to the $10 \mathrm{~L}$ pots. The simulation of conventional tillage treatment was conducted by vigorous mixing and disintegration of the soil by a hoe before transferring it to the pots. The no-tillage treatment was performed by carefully digging and moving the field soil to the pots as one block in an attempt to maintain soil integrity as much as possible.

The pots were placed on stone blocks to prevent the passage of roots to the ground (Figure 2). Each of the pots was filled with water until saturation one week before maize sowing. After this soil initiation, the soils were inoculated with M. maydis—the late wilt disease causal agent, as described in Section 2.3. The pots were sown with the susceptible maize hybrid Prelude cv. on 10 August 2020 . The average temperature was $33 \pm 12.0^{\circ} \mathrm{C}$, and the average humidity was $27 \pm 7.4 \%$. The pots were watered with approximately $2 \mathrm{~L}$ per day per pot and received fertilizers and treatments against various pests according to the Israel Ministry of Agriculture Consultation Service (SAHAM) instructions. The plants were harvested on 20 October 2020, 71 DAS.

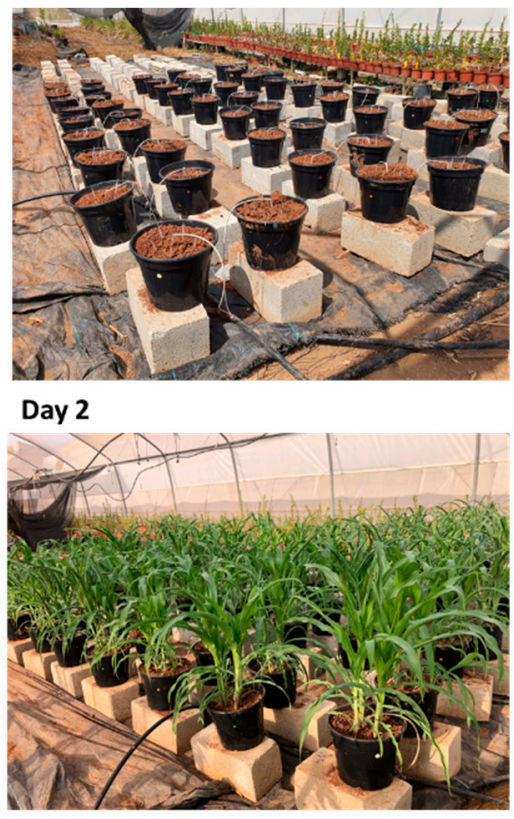

Day 30

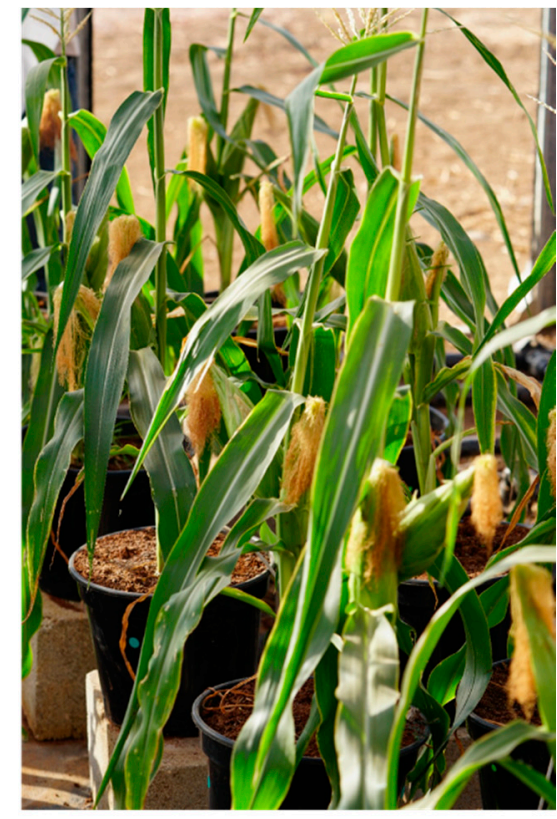

Day 71

Figure 2. The 2020 experiment photo. The study was performed in 10-12 replications of six treatments in pots in a greenhouse throughout a full maize growing season and examined the effect of pregrowth of winter crops (clover or wheat) and maintaining soil integrity (by avoiding tillage) on late wilt disease. Commercial field soil after the winter growing season of clover and wheat and soil after the winter without early winter growing were used. The soils were divided, and simulation of conventional tillage or no-tillage was applied before moving the field soil to $10 \mathrm{~L}$ pots. The soils were inoculated with M. maydis, the late wilt disease causal agent, and sown with the susceptible maize hybrid Prelude cv. 
Emergence percentages evaluation was made 3 DAS. After 43 days, the sprouts were diluted into one plant per pot. On the day of dilution and at the end of the experiment on day 71 of growth, the following indices were examined: plant height, shoot weight, phenological stage, and signs of dehydration. Seasonal variations of the main experiment stages are demonstrated in Figure 2. These stages include the sowing, the end of the sprouting phase (30 DAS, V5-fifth leaf stage, before the female flowering at 56 DAS), and near the harvest (71 DAS). The maize development was normal and correlated to the data in the literature (see [52]).

The dehydration symptoms on the large bracts surrounding the cobs (the spathes) were estimated, as previously described by [16], according to the following scale: 1 -healthy with no signs of dehydration, 2 -minor symptoms up to $20 \%$ of the cob surface, 3-moderate symptoms that cover 30-40\% of the cob surface, and 4-diseased with $50 \%$ or more dehydrated cobs' area. In addition, DNA was extracted from the tissues of 10 plants for treatment, and a qPCR test was made to detect $M$. maydis DNA in the plant tissues (roots on the day of thinning and root and shoot on the harvest). At the end of the experiment, crop evaluation was also performed.

\subsection{Molecular Diagnosis of the Late Wilt Pathogen}

M. maydis target DNA qPCR detection was made for maize plants from all 10 pots of each treatment. Samples were taken from the roots and lower stem (near the first internode) tissues. Plant tissues were washed vigorously under running tap water to remove any visible soil. Tissue sampling was made by cutting a $20 \mathrm{~mm}$ (in length) piece from each plant's lower stem near the aboveground first internode. One repeat was considered as $0.7 \mathrm{~g}$ tissue fresh biomass. A $4 \mathrm{~mL}$ CTAB buffer was added to each plant sample, and the blend was moved into universal extraction bags (Bioreba, Switzerland). The tissue was processed for $5 \mathrm{~min}$ using a hand tissue homogenizer (Bioreba, Switzerland). Then, DNA purification and qPCR-based quantification were conducted according to [31]. The A200a primers were used for qPCR (M. maydis amplified fragment length polymorphismderived species-specific fragment) $[53,54]$. The gene cytochrome c oxidase (COX) encoding the eukaryotic mitochondria respiratory electron transport chain, the last enzyme, was a reference "housekeeping" gene used to normalize the amount of DNA $[55,56]$. The relative gene abundance calculation was made according to the $\Delta \mathrm{Ct}$ model [57]. Similar efficacy was assumed for all samples. All amplifications were performed in triplicate.

\subsection{Statistical Analyses}

A fully randomized statistical design was used in the field observation preparation. Data analysis followed by statistical analysis was made using the JMP program, 15th edition, SAS Institute Inc., Cary, NC, USA. All the data in this manuscript were subjected to the same analytical method. The one-way analysis of variance (ANOVA) tracked by multiple comparisons post hoc of the Student's $t$-test for each pair (without multiple comparisons correction) was used to estimate the differences between the treatments and between the treatments and the controls. In these growth experiments, achieving a uniform infection with M. maydis in Israeli strains is challenging due to natural variations in fungi pathogenesis $[18,50]$. Thus, the molecular DNA measurements resulted in a high level of variations within the results (high standard error values), and statistically significant differences could hardly be identified.

\section{Results}

Strengthening soil microbiome integrity by avoiding aggressive tillage and encouraging specific communities of microorganisms that inhabit a plant's surroundings and roots may enhance soil immunity against plant-parasitic fungi such as the LWD agent, M. maydis. To deepen our understanding towards this end, we conducted two experiments over the 2019 and 2020 winter to summer growth periods. The study was performed as a dual crop with a time interval of 1-3 weeks between crops with and without invasive tillage of the 
soil. We selected wheat and clover as the alternative winter crops to be rotated separately with maize. These two winter crops are prevalent in Israel and are common in the crop cycle with maize in Israel and worldwide.

\subsection{Crop Rotation and Tillage Effect in Pots over a Full Growing Season-The 2019 Experiment}

The dual cultivation greenhouse experiment was conducted during an entire growth period in the winter (wheat and clover season), spring and summer (maize season) of 2019. All treatments had a positive effect on the emergence of the maize plants, evaluated 8 DAS, compared to the control (Table 1). Significant statistical difference $(p<0.05)$ in this measure was found in the commercial mycorrhizal treatment (Resid MG) and the wheat and clover soils after tillage.

Table 1. The 2019 soil microbiome integrity experiment—growth parameters at 22 DAS $^{1}$.

\begin{tabular}{|c|c|c|c|c|c|c|c|c|c|c|c|}
\hline & Tillage & $\begin{array}{c}\text { Emergence } \\
(\%)\end{array}$ & & $\begin{array}{c}\text { Root } \\
\text { Weight (g) }\end{array}$ & & $\begin{array}{c}\text { Shoot } \\
\text { Weight (g) }\end{array}$ & & $\begin{array}{l}\text { Leaves } \\
\text { (No.) }\end{array}$ & & $\begin{array}{l}\text { Height } \\
\text { (cm) }\end{array}$ & \\
\hline Control & - & $78 \% \pm 7 \%$ & B & $0.80 \pm 0.07$ & A & $10.8 \pm 0.8$ & $\mathrm{AB}$ & $6.7 \pm 0.1$ & A & $7.1 \pm 0.3$ & B \\
\hline $\begin{array}{c}\text { Resid } \\
\text { MG }\end{array}$ & - & $94 \% \pm 4 \%$ & A & $0.88 \pm 0.12$ & A & $10.2 \pm 1.5$ & B & $5.8 \pm 1.0$ & B & $10.4 \pm 0.7$ & A \\
\hline \multirow{2}{*}{ Clover } & - & $84 \% \pm 7 \%$ & $\mathrm{AB}$ & $0.79 \pm 0.08$ & A & $13.2 \pm 0.9$ & A & $6.9 \pm 0.2$ & A & $7.4 \pm 0.3$ & B \\
\hline & + & $94 \% \pm 3 \%$ & A & $0.72 \pm 0.06$ & A & $9.5 \pm 1.0$ & B & $7.3 \pm 0.3$ & A & $7.6 \pm 0.3$ & B \\
\hline \multirow{2}{*}{ Wheat } & - & $88 \% \pm 5 \%$ & $\mathrm{AB}$ & $0.85 \pm 0.06$ & $\mathrm{~A}$ & $8.9 \pm 0.6$ & B & $5.8 \pm 0.2$ & B & $11.2 \pm 0.5$ & A \\
\hline & + & $96 \% \pm 4 \%$ & $\mathrm{~A}$ & $0.66 \pm 0.08$ & A & $10.4 \pm 0.8$ & $\mathrm{AB}$ & $7.0 \pm 0.4$ & A & $7.0 \pm 0.4$ & B \\
\hline
\end{tabular}

${ }^{1}$ Emergence percentages were measured eight days after sowing (DAS). All other data were collected after 22 days of growing maize sprouts (Prelude cv.) in a greenhouse. Values represent an average of 10 replications \pm standard error. Statistically significant (one-way ANOVA, $p<0.05)$ differences between treatments at the same measures are indicated by different letters $(\mathrm{A}-\mathrm{B})$.

At 22 DAS, a mixed trend was observed (Table 1). The commercial mycorrhizal treatment significantly improved sprout height but did not affect the other measures. The clover soil without tillage positively and significantly affected shoot weight (without improvement in the other criteria), but this soil's tillage abolished this achievement. In wheat soil, the tillage improved shoot weight but abolished the significant improvement in sprout height recorded in the undisrupted ground. Interestingly, 34 days later, at the fertilization (56 DAS, Table 2), the tillage accelerated the clover soil plants' development (into the R1 stage) and improved plant height in both the clover and wheat soils.

Table 2. The 2019 soil microbiome integrity experiment-growth parameters at 56 DAS $^{1}$.

\begin{tabular}{ccccc}
\hline & Tillage & $\begin{array}{c}\text { Phenological } \\
\text { Development }\end{array}$ & Height (cm) & \\
\hline Control & - & Dis.-1, Vt-1, R1-8 & $140.0 \pm 9.0$ & AB \\
\hline $\begin{array}{c}\text { Resid } \\
\text { MG }\end{array}$ & - & Dis.-2, Vt-5, R1-3 & $125.5 \pm 9.9$ & BC \\
\hline \multirow{2}{*}{ Clover } & - & Vt-4, R1-6 & $117.5 \pm 6.2$ & C \\
& + & Vt-1, R1-9 & $125.5 \pm 3.2$ & BC \\
\hline \multirow{2}{*}{ Wheat } & - & R1-10 & $127.0 \pm 3.4$ & BC \\
& + & Dead-1, Dis.-1, R1-8 & $147.2 \pm 3.1$ & A \\
\hline
\end{tabular}

${ }^{1}$ Values represent an average of 10 replications \pm standard error. Dis. is a shortcut for Diseased. The maize phenological stages are described in [52]. Statistically significant (one-way ANOVA, $p<0.05$ ) differences between treatments at the same measures are indicated by different letters $(A-C)$.

At harvest (77 DAS), maize plants that were grown after wheat acquired significant resistance to late wilt disease, which had not been present in the other treatments (Figure 3). This resistance was affected mainly by an elevation in the healthy plants' proportion, from $10 \%$ in the control to $80 \%$ in the undisturbed wheat soil. The wheat soil 
immunity to late wilt is expressed in growth promotion (Table 3), whereas the highest values were received in shoot weight (significant in both the non-tillage and the tillage soil) and cob weight (significant in the non-tillage soil). Since the dry weight values were similar to all treatments and the control (without statistical significance, Table 4), variations in the plants' fresh weight among the treatments resulted from differences in the water content level rather than in the tissues biomass. The non-tillage wheat soil also led to 5.4-fold reduced DNA of M. maydis within the plants' lower stalk (Figure 4). When commercial mycorrhizal preparation was applied to the ground prior to the maize growing season, an increase in growth parameters was evident compared to the control (Table 3). Yet, this increase was only significantly different.

\section{Dehydration index - 77 DAS}

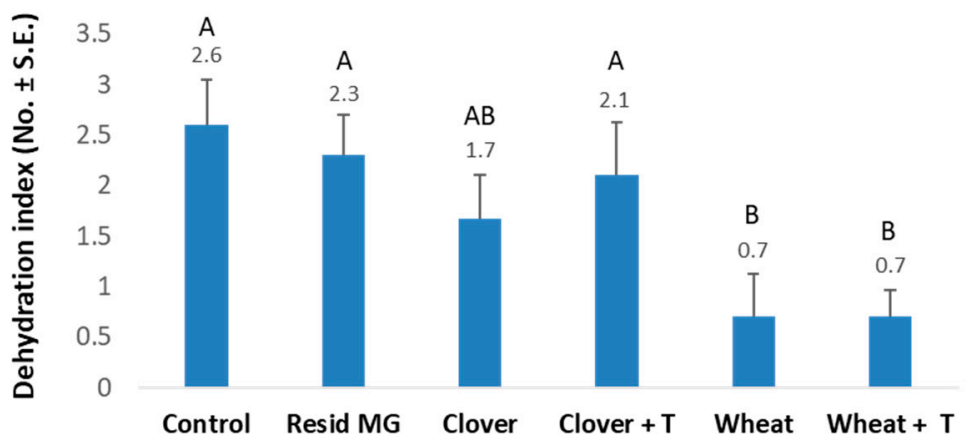

Figure 3. The 2019 soil microbiome integrity experiment-dehydration assessment at the experiment's end (77 DAS). The experiment is described in Figure 1. The controls included the same prior crop soil but with tillage $(+\mathrm{T})$ or soil that had not been cropped before the maize growth (control). Additionally, similar control with commercial Resid MG product (Arbuscular mycorrhizal, Glomus iranicum var. tenuihypharum) was tested. Wilt assessment was based on four categories related to the whole plant: healthy (1), minor symptoms (2), dehydrated (3), and dead (4). Vertical upper bars represent the standard error of the mean of 10 replications. Statistically significant (one-way ANOVA, $p<0.05$ ) differences between treatments at the same measures are indicated by different letters (A-B).

Table 3. The 2019 soil microbiome integrity experiment—growth parameters at 77 DAS $^{1}$.

\begin{tabular}{ccccccccc}
\hline & Tillage & $\begin{array}{c}\text { Phenological } \\
\text { Development }\end{array}$ & $\begin{array}{c}\text { Shoot Wet } \\
\text { Weight (g) }\end{array}$ & & Height (cm) & & \multicolumn{2}{c}{$\begin{array}{c}\text { Cob Wet } \\
\text { Weight (g) }\end{array}$} \\
\hline Control & - & Vt-1, R5-9 & $98.1 \pm 9.8$ & C & $132.5 \pm 8.6$ & AB & $75.7 \pm 6.3$ & B \\
\hline Resid MG & - & R5-10 & $129.5 \pm 9.4$ & ABC & $148.8 \pm 4.6$ & A & $95.2 \pm 10.6$ & AB \\
\hline \multirow{2}{*}{ Clover } & - & R5-10 & $116.2 \pm 15.5$ & BC & $122.5 \pm 9.8$ & B & $87.4 \pm 8.5$ & AB \\
& + & V12-1, R5-9 & $111.7 \pm 13.4$ & BC & $122.5 \pm 10.7$ & B & $92.2 \pm 11.8$ & AB \\
\hline \multirow{2}{*}{ Wheat } & - & Vt-1, R5-9 & $144.1 \pm 10.5$ & AB & $132.9 \pm 6.0$ & AB & $110.9 \pm 9.0$ & A \\
& + & R5-10 & $151.4 \pm 7.0$ & A & $134.6 \pm 7.0$ & AB & $103.1 \pm 11.5$ & AB \\
\hline
\end{tabular}

${ }^{1}$ Values represent an average of 10 replications \pm standard error. Statistically significant (one-way ANOVA, $p<0.05$ ) differences between treatments at the same measures are indicated by different letters $(\mathrm{A}-\mathrm{C})$. 
Table 4. The 2019 soil microbiome integrity experiment—dry weight parameters at 77 DAS ${ }^{1}$.

\begin{tabular}{cccc}
\hline & Tillage & Shoot Dry Weight $(\mathrm{g})$ & Cob Dry Weight $(\mathrm{g})$ \\
\hline Control & - & $59.1 \pm 6.3$ & $47.0 \pm 3.4$ \\
\hline Resid MG & - & $59.6 \pm 6.1$ & $60.8 \pm 7.7$ \\
\hline \multirow{2}{*}{ Clover } & - & $61.3 \pm 8.3$ & $53.9 \pm 6.2$ \\
& + & $47.5 \pm 9.4$ & $48.3 \pm 7.6$ \\
\hline \multirow{2}{*}{ Wheat } & - & $65.5 \pm 3.8$ & $61.7 \pm 7.9$ \\
& + & $60.4 \pm 5.8$ & $65.5 \pm 6.5$
\end{tabular}

${ }^{1}$ Values represent an average of 10 replications \pm standard error. No statistically significant (one-way ANOVA, $p<0.05)$ differences were found between the treatments or between the treatments and the control.

qPCR - 77 DAS

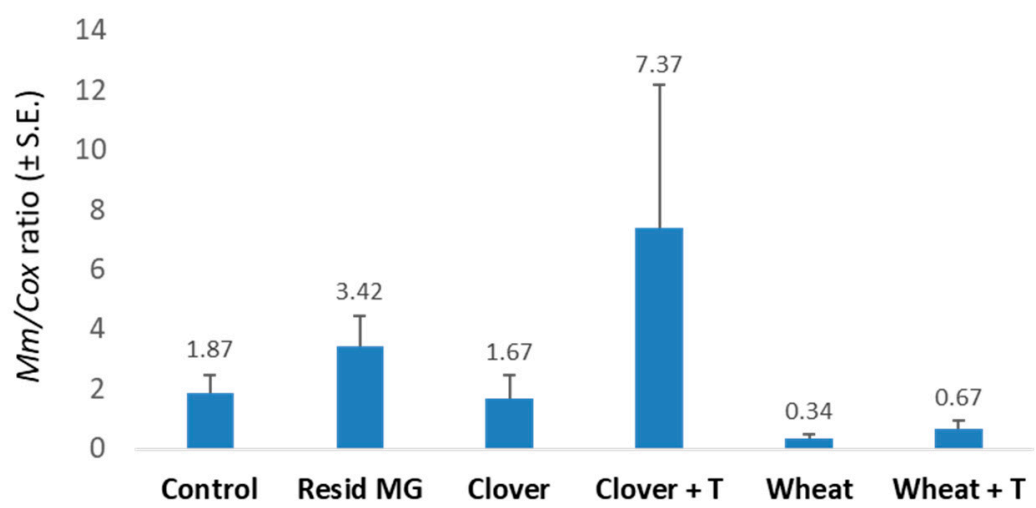

Figure 4. The 2019 soil microbiome integrity experiment-real-time PCR analysis at the experiment's end (77 DAS). The experiment is described in Figure 1. The $y$-axis indicates M. maydis relative DNA $(\mathrm{Mm})$ abundance in the roots normalized to cytochrome c oxidase (COX) DNA. Values indicate an average of 10 replications. Error bars indicate standard error.

\subsection{Evaluation of Commercial Field Soil after Wheat or Clover Growth-The 2020 Experiment}

This follow-up experiment was conducted using the same design as the 2019 experiment. Still, instead of performing a clover and wheat winter growing season in the pots, a commercial field soil of those crops was used. The sprouts' emergence percentages at 3 DAS growth showed a decreasing tendency in the control and clover soil due to the tillage (Table 5). On the other hand, the wheat soil was not affected by tillage in this criterion. The shoot weight values evaluated 43 DAS showed the same tendency, whereas the other growth parameters (the number of leaves and plant height) were only slightly affected by the treatments at that age. The disease severity evaluated by the pathogen DNA spreading in the roots 43 DAS supported the shoot weight values, with the lowest DNA levels in the wheat soil treatment (Figure 5).

At the experiment's end (71 DAS), the fresh shoot weight improved after tillage in the control and wheat soils but was reduced in the clover tillage soil (Table 6). All other growth indices were affected less by pre-cropping or land processing, except for cob weight, which significantly decreased in the wheat soil with tillage. 
Table 5. The 2020 commercial fields soil experiment—growth parameters at 43 DAS $^{1}$.

\begin{tabular}{cccccc}
\hline & Tillage & Emergence (\%) & Shoot Wet Weight (g) & Leaves (no.) & Height (cm) \\
\hline \multirow{2}{*}{ Control } & - & $58 \% \pm 5.5 \%$ & $317.2 \pm 22.4$ & $8.2 \pm 0.4$ & $78.3 \pm 1.2$ \\
& + & $36 \% \pm 7.8 \%$ & $307.8 \pm 24.4$ & $7.8 \pm 0.4$ & $84.0 \pm 3.0$ \\
\hline \multirow{2}{*}{ Clover } & - & $50 \% \pm 10.0 \%$ & $329.2 \pm 20.4$ & $8.1 \pm 0.3$ & $79.7 \pm 2.3$ \\
& + & $44 \% \pm 8.3 \%$ & $303.0 \pm 25.5$ & $8.1 \pm 0.4$ & $81.9 \pm 2.5$ \\
\hline \multirow{2}{*}{ Wheat } & - & $52 \% \pm 9.5 \%$ & $333.4 \pm 17.5$ & $8.1 \pm 0.3$ & $83.9 \pm 3.5$ \\
& + & $50 \% \pm 5.4 \%$ & $345.3 \pm 17.6$ & $7.9 \pm 0.3$ & $84.9 \pm 1.8$ \\
\hline
\end{tabular}

${ }^{1}$ Emergence percentages were measured three days after sowing. All other data were collected after 43 days of growing maize sprouts (Prelude cv.) in a greenhouse. Values represent an average of 10-12 replications \pm standard error. No statistically significant (one-way ANOVA, $p<0.05$ ) differences were found between the treatments or between the treatments and the control.

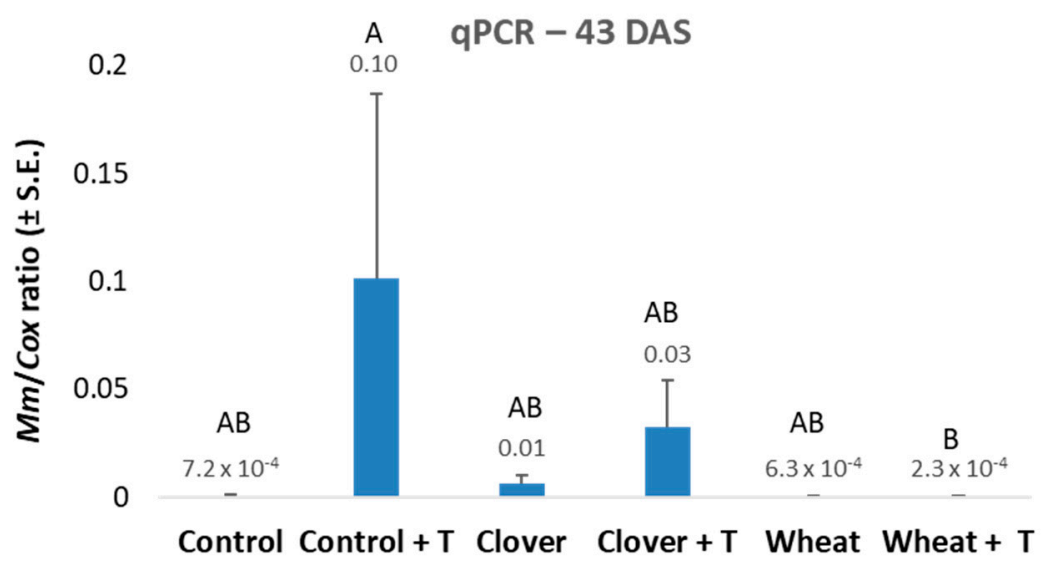

Figure 5. The 2020 commercial fields soil experiment-real-time PCR analysis 43 DAS. The experiment is described in Figure 2. The $y$-axis indicates M. maydis relative DNA abundance in the roots normalized to cytochrome c oxidase (COX) DNA. Values indicate an average of 10-12 replications. Error bars indicate standard error.

Table 6. The 2020 commercial fields soil experiment—growth parameters at the season end, 71 DAS $^{1}$.

\begin{tabular}{ccccccc}
\hline & Tillage & Shoot Weight $(\mathrm{g})$ & Leaves (No.) & $\begin{array}{c}\text { Height } \\
\text { (cm) }\end{array}$ & $\begin{array}{c}\text { Cob Wet } \\
\text { Weight (g) }\end{array}$ & \\
\hline \multirow{2}{*}{ Control } & - & $137.1 \pm 9.4$ & $8.7 \pm 0.4$ & $95.1 \pm 4.6$ & $118.1 \pm 11.0$ & $\mathrm{AB}$ \\
& + & $153.6 \pm 9.4$ & $8.8 \pm 0.3$ & $99.2 \pm 4.2$ & $120.3 \pm 4.5$ & $\mathrm{AB}$ \\
\hline \multirow{2}{*}{ Clover } & - & $153.4 \pm 16.6$ & $8.9 \pm 0.6$ & $100.4 \pm 7.7$ & $125.2 \pm 7.7$ & $\mathrm{~A}$ \\
& + & $146.8 \pm 6.6$ & $8.1 \pm 0.3$ & $102.4 \pm 2.5$ & $122.8 \pm 7.3$ & $\mathrm{~A}$ \\
\hline \multirow{2}{*}{ Wheat } & - & $147.3 \pm 8.2$ & $8.1 \pm 0.2$ & $96.9 \pm 4.1$ & $125.3 \pm 9.0$ & $\mathrm{~A}$ \\
& + & $158.8 \pm 10.3$ & $8.0 \pm 0.3$ & $96.4 \pm 3.1$ & $95.5 \pm 12.1$ & $\mathrm{~B}$
\end{tabular}

${ }^{1}$ Values represent an average of $10-12$ replications. If existing, statistically significant (one-way ANOVA, $p<0.05$ ) differences between treatments at the same measures are indicated by different letters (A-B).

The disease symptoms (Figure 6) and pathogen DNA in the roots and shoots of the plants (Figure 7) evaluated on the harvest day (71 DAS) indicate a positive effect of the wheat soil (with improvement after tillage). This LWD depression was expressed by a significant 2.3-fold decrease in the cobs' dehydration symptoms and a 25-fold and 225-fold reduction in the pathogen's DNA in the plants' roots and shoots, respectively. 
A

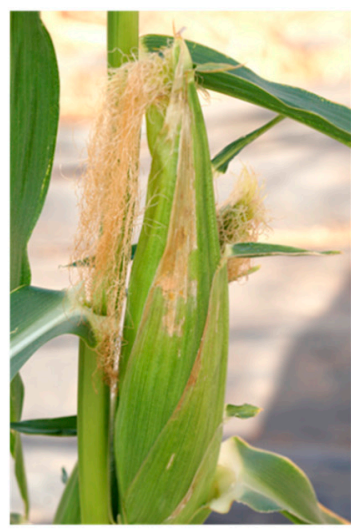

Control

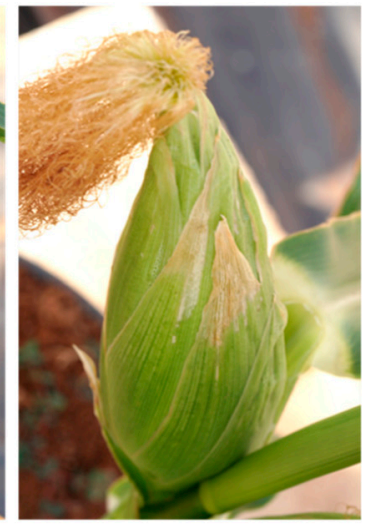

Clover

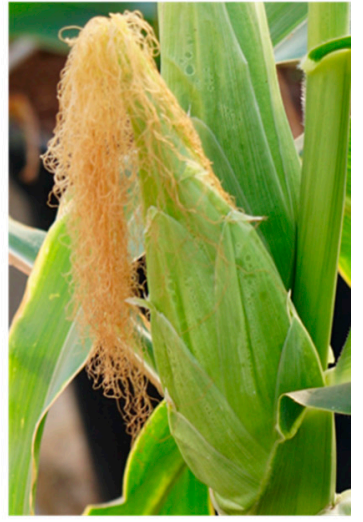

Wheat

B

Dehydration index - 71 DAS

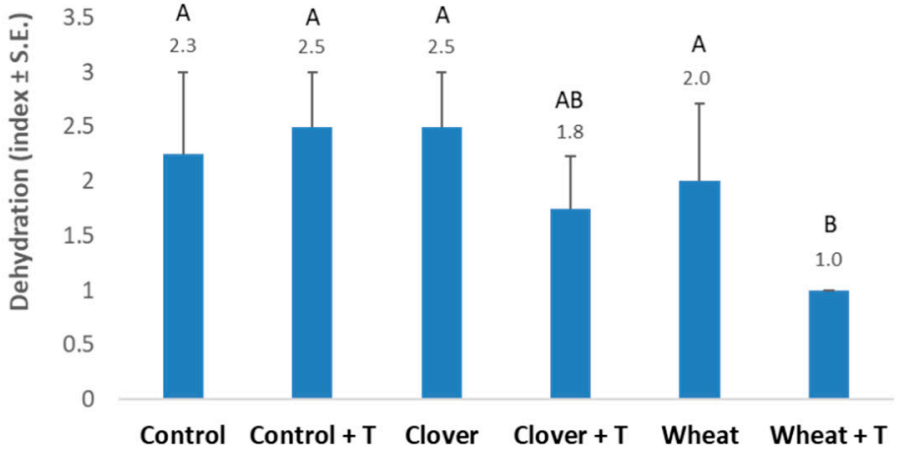

Figure 6. The 2020 commercial fields soil experiment-dehydration assessment on harvest day (71 DAS). The experiment is described in Figure 2. (A) Classification of the cobs' spathes disease symptoms at the end of the 2020 experiment. Representative images of the treatments with varying degrees of late wilt symptoms. (B) Dehydration symptoms on the large bracts surrounding the cobs (the spathes) were estimated according to the following scale: 1 -healthy with no signs of dehydration, 2-minor symptoms up to $20 \%$ of the cob surface, 3-moderate symptoms that cover $30-40 \%$ of the cob surface, and 4 -diseased with $50 \%$ or more dehydrated cobs' area. Values represent an average of 10-12 replications. Error bars indicate standard error. Statistically significant (one-way ANOVA, $p<0.05)$ differences between treatments at the same measures are indicated by different letters (A-B).

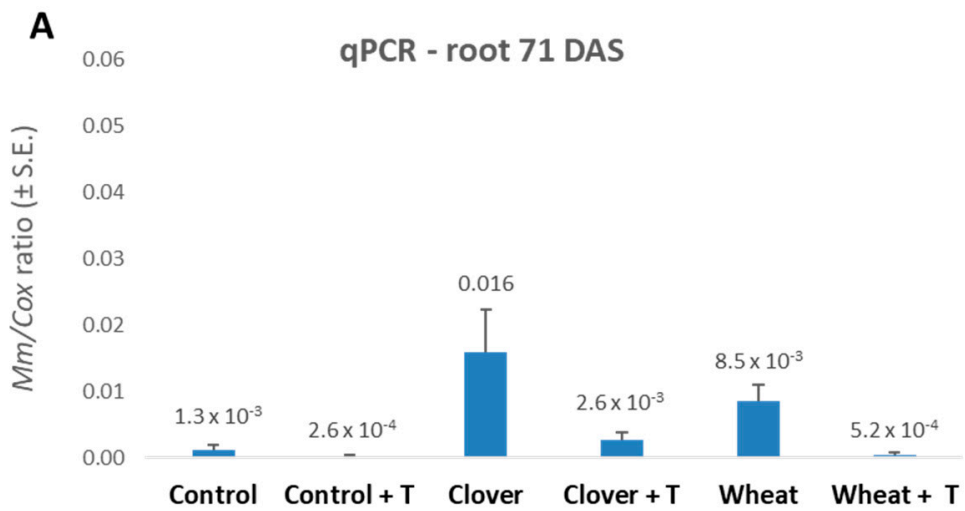

Figure 7. Cont. 


\section{B}

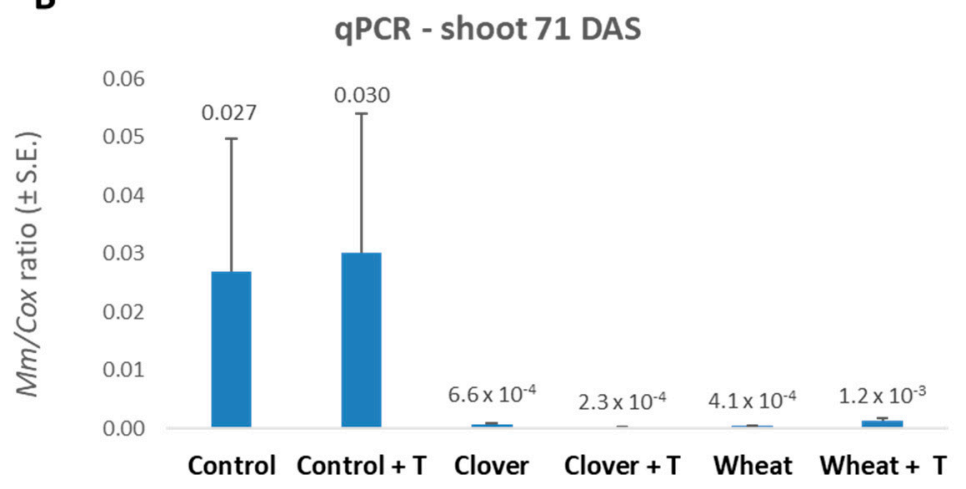

Figure 7. The 2020 commercial fields soil experiment-real-time PCR analysis 71 DAS. The experiment is described in Figure 2. The $y$-axis indicates M. maydis relative DNA abundance in the roots normalized to cytochrome c oxidase (COX) DNA. Values indicate an average of 10-12 replications. Error bars indicate standard error.

\section{Discussion}

The rhizosphere, a soil layer adjacent to the root's surface, is affected by both the presence of a plant and soil properties. This layer has a critical impact on a plant's existence. A significant part of the roots and the whole plant function depends on the "nature of the rhizosphere" and the biological activities within it. Intensive agriculture causes a decrease in microbial biomass in the soil that causes, over time, a decline in soil fertility and yield [58]. Arbuscular mycorrhizal fungi (AMF), which interact with plant roots and other soil fungi, have known benefits in nourishing plants and conferring disease resistance. These properties make them a valuable tool in modern agriculture [48]. The fungus provides the plant with nutrients, affects root morphology, and improves water balance, while the plant provides it with photosynthesis products. These "natural fertilizers" are obligatory symbionts belonging to the phylum Glomeromycota and inhabit $80 \%$ of terrestrial plants [59]. Mycorrhiza has an aggressive antagonism with various plant pathogens and may also be used as a biological pesticide [60].

To date, the use of mycorrhizal fungi to protect field crops is limited due to the high costs (compared to chemical fertilizers) and low biodiversity of the commercial applications offered [59]. This is in addition to the long time required from applying the fungus to achieving efficiency, and in light of the fact that such applications often do not match the intensive growing systems used in agricultural fields. At the same time, mycorrhizal fungi have a wide range of plant hosts. Moreover, using the intact extraradical mycelium method (ERM, preserving the continuity of the mycorrhizal network in the soil) makes it possible to produce a crop sequence that will maintain the mycorrhizal network that promotes the plants' growth and assist in protecting them against soil diseases [61].

Although the worldwide scientific effort is focusing on seeking solutions to LWD based on eco-friendly biological approaches $[16,40,41,43,44,62]$, there is a lack of information on maize performance under LWD stress in crop rotation and reduced tillage. One study that examined this recently [27] showed that grain production and M. maydis presence were significantly reduced when both cover crop and minimum tillage were applied together. It was also found that with cover crop and minimum tillage, the arbuscular root colonization was higher.

The current study did not directly examine the effect of preserving and establishing the mycorrhizal network in the soil to deal with late wilt disease in corn. Instead, it focused, for the first time in Israel, on an agricultural practice based on preserving soil microflora integrity (by avoiding tillage) and affecting its nature (by cultivating selected crops in a dual-season growth). A comparative analysis of the 2019 and the 2020 experiments results at the harvest day is illustrated in Table 7. 
Table 7. Comparative analysis of the 2019 and the 2020 experiments plants' growth and yield results at the harvest day ${ }^{1}$.

\begin{tabular}{cccccc}
\hline \multirow{2}{*}{ Tillage } & \multicolumn{2}{c}{ Shoot Wet Weight (g) } & \multicolumn{2}{c}{ Cob's Wet Weight (g) } \\
\hline \multirow{2}{*}{ Clover } & $\mathbf{2 0 1 9}$ & $\mathbf{2 0 2 0}$ & $\mathbf{2 0 1 9}$ & $\mathbf{2 0 2 0}$ \\
& - & $118 \%$ & $112 \%$ & $115 \%$ & $106 \%$ \\
\multirow{2}{*}{ Wheat } & + & $114 \%$ & $107 \%$ & $122 \%$ & $104 \%$ \\
& - & $147 \%$ & $107 \%$ & $146 \%$ & $106 \%$ \\
\hline
\end{tabular}

${ }^{1}$ Data represent the percent difference compared to the no-tillage and no crop cycle control. Detailed data are described in Table 3 (the 2019 experiment) and Table 6 (the 2020 experiment). Harvest day was 77 DAS in 2019 and 71 DAS in 2020.

When corn was sown on wheat soil, a significant improvement in the fresh weight of the shoot (147-154\% in the 2019 experiment) and cob (136-146\% in the 2019 experiment) was achieved compared to the control. This result was also better than the other treatments (clover soil and commercial mycorrhiza preparation). This achievement was not affected drastically by tillage. It was followed by a sharp decrease in disease symptoms ( $73 \%$ in the 2019 experiment) and the pathogen's presence (82-64\% in the 2019 experiment) in the plants' tissues (Table 8).

Table 8. Comparative analysis of the 2019 and the 2020 experiments plants' health results at the harvest day ${ }^{1}$.

\begin{tabular}{cccccc}
\hline & & \multicolumn{2}{c}{ Diseased Plants } & \multicolumn{2}{c}{ M. maydis DNA } \\
\hline \multirow{2}{*}{ Clover } & Tillage & $\mathbf{2 0 1 9}$ & $\mathbf{2 0 2 0}$ & $\mathbf{2 0 1 9}$ & $\mathbf{2 0 2 0}$ \\
& - & $65 \%$ & $109 \%$ & $89 \%$ & $2 \%$ \\
\multirow{2}{*}{ Wheat } & + & $81 \%$ & $78 \%$ & $394 \%$ & $1 \%$ \\
& - & $27 \%$ & $87 \%$ & $18 \%$ & $2 \%$ \\
& + & $27 \%$ & $43 \%$ & $36 \%$ & $4 \%$ \\
\hline
\end{tabular}

${ }^{1}$ Data represent the percent difference compared to the no-tillage and no crop cycle control. Detailed data are described in Figures 3 and 4 (the 2019 experiment), Figures 6B and 7B (the 2020 experiment). Harvest day was 77 DAS in 2019 and 71 DAS in 2020. The M. maydis DNA levels in the plants' first aboveground internode are presented. In the clover and wheat treatments, the DNA values in the 2020 experiment were similar to those of the 2019 experiment. The low DNA percentages at the 2020 experiment are because of a sharp (23-fold) elevation in the pathogen DNA in the no-tillage and no crop cycle control plants in 2020 compared to 2019.

Interestingly, the 2020 experiment that was based on commercial fields soil resulted in more severe LWD. The disease severity is reflected in higher diseased plants percentages and sharp (23-fold) elevation in the pathogen DNA in the first aboveground internode of the no-tillage control plants (Figure 7, Table 8). This is most likely the reason for the lesser enhancement in the shoot and cobs fresh weight in the clover and wheat treatments (compared to the control) this year (Table 7).

Another intriguing aspect is that at the season-ending, the roots appeared comparatively less affected by the pathogen than the shoot (Figure 7). Indeed, M. maydis high DNA levels in the shoot at this growth stage (the harvest) are well documented in our previous works [3,4]. When an LWD susceptible maize cultivar was seeded on M. maydis heavily infested commercial field soil, the following changes in the pathogen's DNA levels in the host tissues were recorded. When early signs of the disease began to appear from day 50 onwards, the fungal DNA decreased in the roots but increased significantly in the stems until it peaked at 3.2-fold its initial level $72 \mathrm{~d}$ after sowing [3]. These variations in the DNA were consistent with previous literature observations on the disease's mode and the pathogen spread from the roots to the stem, leaves, and kernels [63].

Thus, it appears that since wheat and maize are more closely related than clover and maize (they are both Poaceae), they may share similar mycorrhizal networks that are 
adapted to perform better with these crops. Indeed, in the clover-maize sequence, the above-mentioned growth promotion and LWD resistance were reduced, even more so when tillage was applied.

To support this idea, it was reported that crop plants acquired a mycorrhizal fungal community closely related to that of the previous host plant and different from that found when the soil was disturbed or not cropped before growth [45]. In this last study, wheat grown in undisturbed soil immediately after the legume Ornithopus compressus acquired a mycorrhizal fungal community closely related to that of the last plant host and different from that found when the soil was disturbed or not cropped prior to the growth of the wheat. Parallel effects were seen in the succession from Poaceae (Lolium rigidum) to Fabaceae (Trifolium subterraneum), indicating that these effects are not unique to the legume-wheat sequence.

With the novelty of the current study, it is essential to point out that these trials were conducted over one season, while crop rotation may have a long-term effect on soil fungus populations, which may only be evident after a more extended period. A long-term study on the impact of different crop rotations (including wheat-maize) and tillage regimes (no-tillage or conventional tillage) on microbial biomass and other soil properties was established in 1976 in southern Brazil [58]. The no-tillage system showed increase in microbial biomass percentage at the 0 - to 5-cm depth. Reduction of tillage had a more significant effect on microbial biomass than crop rotations, particularly in the 0-5 cm depth. These results provide evidence that tillage or crop rotation affects microbial immobilization of soil nutrients. The results of this and other studies indicate that no single cropping system is favored for all fungi [64]. Thus, a tailored solution that will address the crops in the rotation, the tillage system, the cultivar that should be protected, and the pathogens/disease stresses should be carefully planned. Such situations should be examined in subsequent studies. Closely related cultivars such as wheat and maize may benefit from the same control strategy.

\section{Conclusions}

The selection of certain plant sequences under standard environmental conditions may lead to the suppression of weeds, insects, and diseases, and the avoidance of yield decline. The current study was performed as a dual crop experiment involving a time interval of one to three weeks between crops with and without invasive tillage of the soil. The LWD was affected differently by the two rotation systems applied here. The effect of crop rotation on the $M$. maydis spreading in the host tissue, plant growth parameters, and LWD symptoms in the wheat-maize sequence was significant. In the wheat soil, all these parameters improved $(p<0.05)$. These results were obtained regardless of the tillage system applied. In contrast, this positive outcome was less prominent in the clover-maize sequence and was reduced even more so when tillage was used. In environments where M. maydis is known at the outset, the choice of cultural conservation practices is essential for maize cultivation, namely, crop cycle, installation of a cover crop, and minimum tillage system. Such green methods could significantly reduce disease pressure and hence assist in reducing the use of fungicides, which have adverse effects on human health and the environment.

Author Contributions: Conceptualization, O.D., A.G., P.B. and S.D.; data curation, O.D., A.G., P.B. and S.D.; formal analysis, O.D., A.G., P.B. and S.D.; funding acquisition, O.D.; investigation O.D., A.G., P.B. and S.D.; methodology, O.D., A.G., P.B. and S.D.; project administration, O.D.; resources, O.D.; supervision, O.D.; validation, O.D.; visualization, O.D., A.G., P.B. and S.D.; writing (original draft), O.D.; writing (review and editing), O.D., A.G., P.B. and S.D. All authors have read and agreed to the published version of the manuscript.

Funding: This study was supported by a research grant from the Tel-Hai College, Israel, Science Relations Foundation (2020).

Institutional Review Board Statement: Not applicable. 
Informed Consent Statement: Not applicable.

Data Availability Statement: The datasets generated during and/or analyzed during the current study are available from the corresponding author on reasonable request.

Acknowledgments: We would like to thank Hagai Shemesh (Tel-Hai College, Qiryat Shemona, Israel) and Onn Rabinovitz (Migal-Galilee Research Institute, Qiryat Shemona, Israel) for their helpful advice. We would also like to thank Danielle Regev (Migal-Galilee Research Institute, Qiryat Shemona, Israel) for her technical assistance. In addition, we would like to thank the BioBee Biological Systems company (Sde Eliyahu, Israel) for supplying the Resid MG preparation.

Conflicts of Interest: The authors declare no conflict of interest. The funders had no role in the design of the study, in the collection, analyses, or interpretation of data, in the writing of the manuscript, or in the decision to publish the results.

\section{References}

1. Olaniyan, A.B. Maize: Panacea for hunger in Nigeria. Afr. J. Plant Sci. 2015, 9, 155-174.

2. Tanklevska, N.; Petrenko, V.; Karnaushenko, A.; Melnykova, K. World corn market: Analysis, trends and prospects of its deep processing. Int. Sci. E-J. Agric. Resour. Econ. 2020, 6, 96-111. [CrossRef]

3. Drori, R.; Sharon, A.; Goldberg, D.; Rabinovitz, O.; Levy, M.; Degani, O. Molecular diagnosis for Harpophora maydis, the cause of maize late wilt in Israel. Phytopathol. Mediterr. 2013, 52, 16-29.

4. Degani, O.; Dor, S.; Movshowitz, D.; Fraidman, E.; Rabinovitz, O.; Graph, S. Effective chemical protection against the maize late wilt causal agent, Harpophora maydis, in the field. PLOS ONE 2018, 13, e0208353. [CrossRef]

5. Al Taweel, H. Mapping of QTLs for Resistance to Late Wilt of Maize in Egypt Using SNPs. Master's Thesis, The American University in Cairo Digital Archive and Research Repository, Cairo, Egypt, 2013.

6. Rakesh, B.; Gangappa, E.; Sonali, G.; Gowda, R.P.V.; Swamy, S.D.; Ramesh, S.; Hemareddy, H.B.; Nagaraju, N. Modified method of screening maize inbred lines to late wilt disease caused by Harpophora maydis. Mysore J. Agric. Sci. 2016, 50, 684-690.

7. Sunitha, N.; Gangappa, E.; Gowda, R.V.; Ramesh, S.; Biradar, S.; Swamy, D.; Hemareddy, H.J. Assessment of impact of late wilt caused by Harpophora maydis (Samra, Sabet and Hing) on grain yield and its attributing traits in maize (Zea mays L.). Mysore J. Agric. Sci. 2020, 54, 30-36.

8. Molinero-Ruiz, M.L.; Melero-Vara, J.M.; Mateos, A. Cephalosporium maydis, the Cause of Late Wilt in Maize, a Pathogen New to Portugal and Spain. Plant Dis. 2010, 94, 379. [CrossRef] [PubMed]

9. Klaubauf, S.; Tharreau, D.; Fournier, E.; Groenewald, J.Z.; Crous, P.W.; de Vries, R.P.; Lebrun, M.H. Resolving the polyphyletic nature of Pyricularia (Pyriculariaceae). Stud. Mycol 2014, 79, 85-120. [CrossRef] [PubMed]

10. Samra, A.S.; Sabet, K.A.; Hingorani, M.K. Late wilt disease of maize caused by Cephalosporium maydis. Phytopathology 1963, 53, 402-406.

11. Gams, W. Phialophora and some similar morphologically little-differentiated anamorphs of divergent ascomycetes. Stud. Mycol. 2000, 45, 187-200.

12. Saleh, A.A.; Leslie, J.F. Cephalosporium maydis is a distinct species in the Gaeumannomyces-Harpophora species complex. Mycologia 2004, 96, 1294-1305. [CrossRef]

13. Tej, R.; Rodríguez-Mallol, C.; Rodríguez-Arcos, R.; Karray-Bouraoui, N.; Molinero-Ruiz, L. Inhibitory effect of Lycium europaeum extracts on phytopathogenic soil-borne fungi and the reduction of late wilt in maize. Eur. J. Plant Pathol. 2018, 152, $249-265$. [CrossRef]

14. Samra, A.S.; Sabet, K.A.; Hingorani, M.K. A new wilt disease of maize in Egypt. Plant Dis. Rep. 1962, 46, 481-483.

15. Ortiz-Bustos, C.; López-Bernal, A.; Testi, L.; Molinero-Ruiz, L.J. Environmental and irrigation conditions can mask the effect of Magnaporthiopsis maydis on growth and productivity of maize. Plant Pathol. 2019, 68, 1555-1564. [CrossRef]

16. Degani, O.; Rabinovitz, O.; Becher, P.; Gordani, A.; Chen, A. Trichoderma longibrachiatum and Trichoderma asperellum Confer Growth Promotion and Protection against Late Wilt Disease in the Field. J. Fungi 2021, 7, 444. [CrossRef]

17. Degani, O.; Cernica, G. Diagnosis and Control of Harpophora maydis, the Cause of Late Wilt in Maize. Adv. Microbiol. 2014, 4, 94-105. [CrossRef]

18. Degani, O.; Movshowitz, D.; Dor, S.; Meerson, A.; Goldblat, Y.; Rabinovitz, O. Evaluating Azoxystrobin Seed Coating Against Maize Late Wilt Disease Using a Sensitive qPCR-Based Method. Plant Dis. 2019, 103, 238-248. [CrossRef]

19. Michail, S.H.; Abou-Elseoud, M.S.; Nour Eldin, M.S. Seed health testing of corn for Cephalosporium maydis. Acta Phytopathol. Entomol. Hung. 1999, 34, 35-42.

20. Sabet, K.A.; Samra, A.S.; Mansour, I.M. Saprophytic behaviour of Cephalosporium maydis and C. acremonium. Ann. Appl. Biol. 1970, 66, 265-271. [CrossRef]

21. Sahab, A.F.; Osman, A.R.; Soleman, N.K.; Mikhail, M.S. Studies on root-rot of lupin in Egypt and its control. Egypt. J. Phytopathol. 1985, 17, 23-35.

22. Degani, O.; Dor, S.; Abraham, D.; Cohen, R. Interactions between Magnaporthiopsis maydis and Macrophomina phaseolina, the Causes of Wilt Diseases in Maize and Cotton. Microorganisms 2020, 8, 249. [CrossRef] 
23. Sabet, K.; Samra, A.; Mansour, I. Interaction between Fusarium oxysporum f. vasinfectum and Cephalosporium maydis on cotton and maize. Ann. Appl. Biol. 1966, 58, 93-101. [CrossRef]

24. Dor, S.; Degani, O. Uncovering the Host Range for Maize Pathogen Magnaporthiopsis maydis. Plants 2019, 8, 259. [CrossRef]

25. Singh, S.; Siradhana, B. Effect of macro and micronutrients on the development of late wilt of maize induced by Cephalosporium maydis. Summa Phytopathol. 1990, 16, 140-145.

26. Samra, A.S.; Sabet, K.A.; Abdel-Rahim, M.F. Effect of Soil Conditions and Cultural Practices on Infection with Stalk Rots; U.A.R. Ministry of Agric. Government Printing Offices: Cairo, Egypt, 1966; pp. 117-164.

27. Patanita, M.; Campos, M.D.; Félix, M.d.R.; Carvalho, M.; Brito, I. Effect of tillage system and cover crop on maize mycorrhization and presence of Magnaporthiopsis maydis. Biology 2020, 9, 46. [CrossRef]

28. Singh, S.D.; Siradhana, B.S. Influence of some environmental conditions on the development of late wilt of maize induced by Cephalosporium maydis. Indian J. Mycol. Plant Pathol. 1987, 17, 1-5.

29. Fayzalla, E.; Sadik, E.; Elwakil, M.; Gomah, A. Soil solarization for controlling Cephalosporium maydis, the cause of late wilt disease of maize in Egypt. Egypt J. Phytopathol. 1994, 22, 171-178.

30. Abd-el-Rahim, M.F.; Sabet, K.A.; El-Shafey, H.A.; El-Assiuty, E.M. Chemical control of the late-wilt disease of maize caused by Cephalosporium maydis. Agric. Res. Rev. 1982, 60, 31-49.

31. Degani, O.; Dor, S.; Chen, A.; Orlov-Levin, V.; Stolov-Yosef, A.; Regev, D.; Rabinovitz, O. Molecular Tracking and Remote Sensing to Evaluate New Chemical Treatments against the Maize Late Wilt Disease Causal Agent, Magnaporthiopsis maydis. J. Fungi 2020, 6, 54. [CrossRef] [PubMed]

32. Degani, O.; Weinberg, T.; Graph, S. Chemical control of maize late wilt in the field. Phytoparasitica 2014, 42, 559-570. [CrossRef]

33. Singh, S.D.; Siradhana, B.S. Chemical control of late wilt of maize induced by Cephalosporium maydis. Indian J. Mycol. Plant Path. $1989,19,121-122$.

34. Ghazy, N.; El-Gremi, S.; Belal, E.-S. Chemical and Histological Differences of Corn (Zea mays L.) Responsive to Harpophora maydis Infection. Environ. Biodivers. Soil Secur. 2017, 1, 3-7. [CrossRef]

35. El-Shafey, H.A.; El-Shorbagy, F.A.; Khalil, I.I.; El-Assiuty, E.M. Additional sources of resistance to the late-wilt disease of maize caused by Cephalosporium maydis. Agric. Res. Rev. Egypt 1988, 66, 221-230.

36. Ortiz-Bustos, C.M.; Testi, L.; García-Carneros, A.B.; Molinero-Ruiz, L. Geographic distribution and aggressiveness of Harpophora maydis in the Iberian peninsula, and thermal detection of maize late wilt. Eur. J. Plant Pathol. 2015, 144, 383-397. [CrossRef]

37. Zeller, K.A.; Ismael, A.M.; El-Assiuty, E.M.; Fahmy, Z.M.; Bekheet, F.M.; Leslie, J.F. Relative Competitiveness and Virulence of Four Clonal Lineages of Cephalosporium maydis from Egypt Toward Greenhouse-Grown Maize. Plant Dis. 2002, 86, 373-378. [CrossRef]

38. Avila-Adame, C.; Koller, W. Characterization of spontaneous mutants of Magnaporthe grisea expressing stable resistance to the Qo-inhibiting fungicide azoxystrobin. Curr. Genet. 2003, 42, 332-338. [CrossRef] [PubMed]

39. Ons, L.; Bylemans, D.; Thevissen, K.; Cammue, B.P.A. Combining Biocontrol Agents with Chemical Fungicides for Integrated Plant Fungal Disease Control. Microorganisms 2020, 8, 1930. [CrossRef] [PubMed]

40. Ghazy, N.; El-Nahrawy, S. Siderophore production by Bacillus subtilis MF497446 and Pseudomonas koreensis MG209738 and their efficacy in controlling Cephalosporium maydis in maize plant. Arch. Microbiol. 2021, 203, 1195-1209. [CrossRef] [PubMed]

41. Elshahawy, I.E.; El-Sayed, A.E.-K.B. Maximizing the efficacy of Trichoderma to control Cephalosporium maydis, causing maize late wilt disease, using freshwater microalgae extracts. Egypt. J. Biol. Pest. Control. 2018, 28, 48. [CrossRef]

42. Gal-Hemed, I.; Atanasova, L.; Komon-Zelazowska, M.; Druzhinina, I.S.; Viterbo, A.; Yarden, O. Marine isolates of Trichoderma spp. as potential halotolerant agents of biological control for arid-zone agriculture. Appl. Environ. Microbiol. 2011, 77, 5100-5109. [CrossRef]

43. Degani, O.; Danielle, R.; Dor, S. The microflora of maize grains as a biological barrier against the late wilt causal agent, Magnaporthiopsis maydis. Agronomy 2021, 11, 965. [CrossRef]

44. Degani, O.; Dor, S. Trichoderma Biological Control to Protect Sensitive Maize Hybrids against Late Wilt Disease in the Field. J. Fungi 2021, 7, 315. [CrossRef] [PubMed]

45. Brígido, C.; van Tuinen, D.; Brito, I.; Alho, L.; Goss, M.J.; Carvalho, M. Management of the biological diversity of AM fungi by combination of host plant succession and integrity of extraradical mycelium. Soil Biol. Biochem. 2017, 112, 237-247. [CrossRef]

46. Sharma, M.; Sudheer, S.; Usmani, Z.; Rani, R.; Gupta, P. Deciphering the omics of plant-microbe interaction: Perspectives and new insights. Curr. Genom. 2020, 21, 343-362. [CrossRef]

47. Diagne, N.; Ngom, M.; Djighaly, P.I.; Fall, D.; Hocher, V.; Svistoonoff, S. Roles of arbuscular mycorrhizal fungi on plant growth and performance: Importance in biotic and abiotic stressed regulation. Diversity 2020, 12, 370. [CrossRef]

48. Martín, F.F.; Molina, J.J.; Nicolás, E.N.; Alarcón, J.J.; Kirchmair, M.; García, F.J.; Garcia, A.J.B.; Bernal, C. Application of Arbuscular Mycorrhizae Glomus iranicum var. tenuihypharum var. nova in Intensive Agriculture: A study case. J. Agric. Sci. Technol. B 2017, 7, 221-247.

49. Degani, O.; Goldblat, Y. Ambient Stresses Regulate the Development of the Maize Late Wilt Causing Agent, Harpophora maydis. Agric. Sci. 2014, 5, 571-582. [CrossRef]

50. Degani, O.; Regev, D.; Dor, S.; Rabinovitz, O. Soil bioassay for detecting Magnaporthiopsis maydis infestation using a hyper susceptible maize hybrid. J. Fungi 2020, 6, 107. [CrossRef] [PubMed] 
51. Degani, O.; Dor, S.; Movshovitz, D.; Rabinovitz, O. Methods for Studying Magnaporthiopsis maydis, the Maize Late Wilt Causal Agent. Agronomy 2019, 9, 181. [CrossRef]

52. Abendroth, L.J.; Elmore, R.W.; Boyer, M.J.; Marlay, S.K. Corn Growth and Development; PM\&R: Ames, IA, USA, 2011.

53. Saleh, A.A.; Zeller, K.A.; Ismael, A.S.; Fahmy, Z.M.; El-Assiuty, E.M.; Leslie, J.F. Amplified Fragment Length Polymorphism Diversity in Cephalosporium maydis from Egypt. Phytopathology 2003, 93, 853-859. [CrossRef]

54. Zeller, K.A.; Jurgenson, J.E.; El-Assiuty, E.M.; Leslie, J.F. Isozyme and amplified fragment length polymorphisms from Cephalosporium maydis in Egypt. Phytoparasitica 2000, 28, 121-130. [CrossRef]

55. Li, W.; Hartung, J.S.; Levy, L. Quantitative real-time PCR for detection and identification of Candidatus Liberibacter species associated with citrus huanglongbing. J. Microbiol. Methods 2006, 66, 104-115. [CrossRef]

56. Weller, S.; Elphinstone, J.; Smith, N.; Boonham, N.; Stead, D. Detection of Ralstonia solanacearumstrains with a quantitative, multiplex, real-time, fluorogenic PCR (TaqMan) assay. Appl. Environ. Microbiol. 2000, 66, 2853-2858. [CrossRef]

57. Yuan, J.S.; Reed, A.; Chen, F.; Stewart, C.N., Jr. Statistical analysis of real-time PCR data. BMC Bioinform. 2006, 7, 85. [CrossRef]

58. Balota, E.L.; Colozzi-Filho, A.; Andrade, D.S.; Dick, R.P. Microbial biomass in soils under different tillage and crop rotation systems. Biol. Fertil. Soils 2003, 38, 15-20. [CrossRef]

59. Berruti, A.; Lumini, E.; Balestrini, R.; Bianciotto, V. Arbuscular mycorrhizal fungi as natural biofertilizers: Let's benefit from past successes. Front. Microbiol. 2016, 6, 1559. [CrossRef] [PubMed]

60. Tahat, M.; Sijam, K.; Othman, R. Mycorrhizal fungi as a biocontrol agent. Plant Pathol. J. 2010, 9, 198-207. [CrossRef]

61. Brito, I.; Goss, M.; Alho, L.; Brígido, C.; van Tuinen, D.; Félix, M.; Carvalho, M. Agronomic management of AMF functional diversity to overcome biotic and abiotic stresses-The role of plant sequence and intact extraradical mycelium. Fungal Ecol. 2019, 40, 72-81. [CrossRef]

62. El-Shabrawy, E.-S.; Shehata, H. Controlling maize late-wilt and enhancing plant salinity tolerance by some rhizobacterial strains. Egypt. J. Phytopathol. 2018, 46, 235-255. [CrossRef]

63. Sabet, K.A.; Zaher, A.M.; Samra, A.S.; Mansour, I.M. Pathogenic behaviour of Cephalosporium maydis and C. acremonium. Ann. Appl. Biol. 1970, 66, 257-263. [CrossRef]

64. Smit, E.; Van Rensburg, G.D.J.; Rijkenberg, F. Number of isolates of maize root fungi in different crop rotation systems. South Afr. J. Plant Soil 1997, 14, 127-130. [CrossRef] 